\title{
Near-Death Visions of Unborn Children: Indications of a Pre-Earth Life
}

\author{
Craig R. Lundahl, Ph.D. \\ Western New Mexico University
}

\begin{abstract}
A limited number of accounts of near-death visions that include unborn children suggest a life before birth. The unborn children in these visions have been described as spirits, as children or children but full-grown, and as residing in another world, perhaps different from the realm of the afterlife. The arrival of these children into our earthly world is similar to the departure of near-death experiencers into the other world.
\end{abstract}

Almost two decades of near-death research has clearly documented the phenomenon of the near-death experience (NDE). Among NDE accounts collected over this time are a limited number that are suggestive of a life before birth. Several researchers have published NDE accounts in which experiencers have seen individuals they identified as persons who had not yet been born. Craig Lundahl (1982, in press) described two NDEs in which the experiencers were shown the spirits of children who would come into their families.

Howard Mickel described the NDE of Calvin, who saw a group of young children playing together during his journey to the other world. Calvin's "eyes fastened upon one and a message was instantly impressed upon his mind that this was his little unborn son" (Mickel, 1985, p. 31). Melvin Morse and Paul Perry (1990) wrote about the childhood NDE of Katie, who while in the other world made new friends, among them two young boys who were waiting to be born.

Craig R. Lundahl, Ph.D., is Professor of Sociology and Business Administration and Chair of the Department of Social Sciences at Western New Mexico University. 
Kenneth Ring (1980) mentioned the case of a NDEr who experienced a life review in which she saw the backs of two children she would give birth to in the future. Arvin Gibson (1992) also cites a case where an experiencer saw a male spirit who would be her child.

Even though mention of this event in NDEs is rare, it still deserves exploration if for no other reason than that it is consistent with and supportive of another element of NDEs, namely the experiencers' moving to another sphere or dimension after death. Seeing unborn children in the NDE suggests that people move into this earthly sphere from another realm, just as the NDE suggests that we can move from this sphere into another realm upon death. These visions of unborn children in the NDE could also broaden our perspective surrounding life and the NDE and add to our understanding of human development.

The purpose of this paper is to document this rare aspect of the NDE, visions of unborn children, which heretofore has gone unrecognized in near-death studies.

\section{Visions of Unborn Children}

Three NDE accounts document the observation of unborn children in NDEs and furthermore provide some understanding of this aspect of NDEs. The first NDE account, as told by the experiencer's granddaughter, is of a Canadian woman in 1913 who saw two unborn children in the other world who later became her children on earth:

As they moved the family continued to grow, until 1913, while living in Alberta, Canada, Bertha had given birth to 13 children. After much deliberation, she decided that life was just too difficult for her to bring any more children into the world.

It wasn't long afterwards that Bertha became seriously ill. I don't remember the nature of the illness, only that it was sufficiently serious that a nurse whom Bertha called Sister Edwards came to the home to care for her. In those days, in remote rural communities, going to hospitals was usually out of the question.

With Sister Edwards sitting beside her bed, Bertha suddenly real. ized she was rising in the air above her bed, the pain and discomfort of a few moments earlier was suddenly gone. As she looked down at her bed, she could see Sister Edwards sitting beside the bed.

Thinking Bertha had died, Sister Edwards later said she wanted to call to the others in the house, but was prompted to do nothing. She had a peaceful feeling that everything would be all right if she just waited a few minutes.

Bertha felt relieved. The pain was gone. She was so full of peace, that she had no particular desire to return to her body. 
She was greeted by a woman who escorted her into a large room where she was greeted by many of her departed friends. One was a young man she had befriended and encouraged to develop his artistic talents. He was sitting in front of an easel, painting. Though he was very happy to see Bertha, he quickly returned to his work as though his time was very precious.

Bertha was taken into another room where there were many children. On the far side of the room she saw two little girls, whom she did not know. They were so beautiful she could not look away from them.

"Do you want them?" the guide asked.

"Yes. Oh, yes," she responded quickly. "Can I return to earth life and have them?"

"Yes," said the escort. "That is the purpose of this visit, to let you see them. Now we must return." Bertha returned to her body, much to the relief of Sister Edwards. After recovering from the illness, Bertha told Jonathan [her husband] she wanted more children.

A year later, after moving to Oakly, Idaho, Bertha gave birth to a new little girl whom she named Alberta. Two years later she delivered another little girl, LaVirle. For the remainder of her life, Bertha insisted these were the two little girls she had seen in the large room. (Nelson, 1988, pp. 37-39)

In a second NDE account, a woman pregnant with her third child started hemorrhaging and underwent surgery. She related the following:

I felt my spirit kind of gathering to the middle of my body, then draining out the back. I found myself in the corner of the room, floating in mid-air, watching the doctor and nurses trying to revive the body on the operating table.

I felt like I could go back to my body but didn't want to. Suddenly I was aware of a dark tunnel, like a doorway leaving the operating room. I could see it, but the doctors and nurses couldn't. Though I was afraid, I entered the tunnel and found myself traveling very fast towards the far end. I wasn't walking or running, just floating along, very fast. There was a light at the end of the tunnel. It wasn't a blue light, but a warm golden light, very bright. As I neared the end of the tunnel it became very narrow, but I made it through, finding myself in an open place with other people....

Against the doctor's advice, I became pregnant four more times, losing two of the babies prematurely, coming near death again with another of the pregnancies. I knew that several of the people I had seen at the end of the tunnel were to be my future children, so I continued getting pregnant until I felt I had brought them into the world. (Nelson, 1988, pp. 107-109)

One male NDEr, who was crushed by a hay derrick in August, 1920, stated: 
My Guide then took me and showed me the spirits of the children that would yet come to my family if we would be faithful. They were full grown but not in the same sphere as those which had lived upon the earth. (Crowther, 1967, p. 39)

Each of these three published NDE accounts contains unborn children seen by the NDEr. They seem to suggest that persons who live on the earth have a pre-earth life in another sphere or dimension. This is exactly what the NDEr, Betty Eadie (1992), learned when she was reintroduced to two women who were her close friends before she came to earth and when she was taken to a place where spirits prepare for life on earth and saw one who was just entering his mother's womb.

\section{Coming to Earth}

One might ask how these unborn children in NDEs come to this earth from their sphere. One NDE account in particular addressed this process:

When I am pregnant, I have a hormone imbalance that affects my entire glandular system. Although I have sought the best medical advice available, when I am expecting I become seriously ill, and have lost nine out of my eleven pregnancies.

During one of these pregnancies, I became so weak and tired that I could not walk across the room to call on the phone for help. I was having very heavy contractions and knew that I was not going to make it through that pregnancy....

Only a few moments later, my husband came in to check on me. I was unspeakably relieved that he had come home, and as I tried to ask him for help, I started to miscarry. The physical labor was too much for my body because of my weakened condition. My body stayed right there, but my spirit started leaving. My husband began slapping my face, yet I couldn't respond. I knew that I was passing on, and I watched myself leaving.

Suddenly I started going through dimensions. There is no way to describe what happened. I was moving through our physical dimension into another one....

Before I reached the light, I recalled my life in a sudden flash. It was the most totally exciting, fantastic thing I have ever seen. I saw the time I was brought from heaven to the earth by angels to a body, how I was received at the hospital, and how my parents loved me. From that day until the present, I saw everything that ever happened to me in my life. It was all in an instant, at fantastic speeds and rates, and it was not like a day-to-day procedure. What I saw was like a concept to learn or a trial, experience by experience. My life was arranged systematically so that everything related to one subject or trial was 
grouped together. At the end of each experience I was judged. There was no voice of judgment, but I knew instantly how the Lord felt about each thing I had done in my life. I was also able to perceive how my actions affected everyone around me. I had never even thought about my influence on others as part of my judgment before, only what I had done. (Sorensen and Willmore, 1988, pp. 89-91)

Later in the NDE, this woman also saw an unborn child. She stated, "I was shown another child that I would have if I returned [to life]" (Sorensen and Willmore, 1988, p. 93).

What is particularly important about this NDE account for purposes of this paper is the description by this woman of what she saw in her life review pertaining to her arrival in this world: "I was brought from heaven to earth by angels to a body." This will sound familiar to neardeath researchers because it is similar to what they have heard from many NDErs who leave this world while near death. In other words, the spirit appears to enter the body at birth or near birth and to leave the body near death, and it is escorted by another being or beings in this process (Lundahl, 1992).

\section{Conclusion}

In eight published NDE accounts, experiencers described seeing unborn children. An examination of these few accounts shows that in at least one instance these children were seen as spirits, which is consistent with the spiritual bodies NDErs seem to have when leaving the physical body while near death. In some NDEs these unborn children are pointed out to the NDEr, and in other NDEs the experiencer in some way is mentally aware that a particular individual or individuals are waiting to be born. In almost every account of these unborn children, they are to come to the NDEr's family. The unborn children are also seen as children in every account, with one exception in which they were described as children but full grown. In almost every NDE account involving unborn children, they are seen in the other world, although in one account it was specifically mentioned that these unborn children are not in the same sphere as those who have lived on the earth, indicating the possibility of different spheres for prenatal and postmortem persons. Based on information from one NDE account, these unborn children's arrival in our earthly world is similar to the departure of NDErs to the other world.

This paper is an elementary description of an aspect of the NDE not examined previously. Further study by other researchers on NDE 
visions of unborn children and their features is needed if we are to gain more in-depth information on this aspect of the NDE and its meaning.

\section{References}

Crowther, D. S. (1967). Life everlasting. Salt Lake City, UT: Bookcraft.

Eadie, B. J., and Taylor, C. (1992). Embraced by the light. Placerville, CA: Gold Leaf Press.

Gibson, A. S. (1992). Glimpses of eternity. Bountiful, UT: Horizon.

Lundahl, C. R. (Ed.). (1982). A collection of near-death research readings. Chicago, IL: Nelson-Hall.

Lundahl, C. R. (1992). Angels in near-death experiences. Journal of Near-Death Studies, $11,49-56$.

Lundahl, C. R. (In press). Otherworld personal future revelations in near-death experiences. Journal of Near-Death Studies.

Mickel, H. (1985). The near-death experience. Wichita, KS: Theta Project.

Morse, M., and Perry, P. (1990). Closer to the light: Learning from the near-death experiences of children. New York, NY: Villard.

Nelson, Lee. (1988) Beyond the veil. Volume I. Orem, UT: Cedar Fort.

Ring, K. (1980). Life at death: A scientific investigation of the near-death experience. New York, NY: Coward, McCann, and Geoghegan.

Sorensen, M. R., and Willmore, D. R. (1988). The journey beyond life. Orem, UT: Family Affair Books. 